\title{
Training and knowledge transfer at the interface of cultures
}

Ph.D. Renata Winkler Cracow University of Economics

\section{Introduction}

The shift of the employment paradigm, which is taking place $^{1}$, in combination with dynamic demographic transformations of the world population and the extension of the territorial scope of activities by organizations translate into a higher level of cultural heterogeneity of the human resources of the organization. Thereby, both from the point of view of the management theory and practice, there has been an increase of interest in the problems of the cultural diversity of personnel and the issues of the functioning of multicultural teams. At the same time, knowledge has been recognized as one of the most strategic organizational resources, except human resources. Nowadays in publications in the field of management the issue of knowledge management is subject to analysis in a greater extent, in particular in terms of generation, capture, storage, dissemination, appropriation and application of knowledge. It is assumed that the process of knowledge transfer becomes the essence of creating new knowledge and maximizing its value (Kang, Rhee, Kang 2010, p. 2). It is also assumed that

1 From exclusive, permanent into simultaneous, temporary and calculative (Sikorski 2000, p. 167). 
the cultural distance and related diversity of cultural standards referring to the assessment of the world makes the process of knowledge transfer at the interface of diverse cultures more complex and more difficult to realize than within a single culture (i.e. in the case of culturally homogenous groups) (Niederman 2005, p. 189; Qin, Ramburuth, Wang 2008, pp. 260-261).

Since training within the organization is perceived not only as a basic form of supporting the development of employees (helping develop the competences and skills of the staff and useful in the context of creating appropriate attitudes of employees), but also as a tool, both necessary in the process of generating new knowledge, and its transfer, and in the economic practice, the process of knowledge transfer, in the majority of cases, turns out to be extremely tedious, time-consuming and difficult (Szulanski 2000, p. 10; Argote, Ingram 2000, p. 151), both from the point of view of theory and practice, the analysis of possibilities of using training in a culturally diverse environment seems to be extremely interesting - in the context of the issue of knowledge transfer. Such a goal was adopted for implementation by the author of the study. Taking the discussion within the identified problem the author decided to carry out a qualitative research method: desk research ${ }^{2}$

\section{Knowledge transfer}

Knowledge transfer includes any action, under which there is disclosure to others what an individual knows. This process is not only limited to the relocation of a particular body of knowledge, but it also includes the modification of the transferred knowledge for the purpose of adapting it to be used in another context (Kumar, Ganesh 2009, p. 163). In the subject literature a knowledge sharing process (the process of knowledge sharing shall be referred to a bilateral interpersonal process, within which individuals mutually share knowledge) and knowledge reuse are treated as the sub-processes of transfer (Majchrzak, Cooper, Neece 2004, p. 174).

In traditional approaches of the transfer, knowledge was perceived in the category of object (resource) that could be transmitted mechanically between "actors of knowledge": from knowledge producers (researchers) to translators

2 I.e. the analysis of secondary resources, with regard to the available results of meta-analyses published in the subject literature, the selection is mainly motivated by the fact that the studies of knowledge transfer are not only complex, but also extremely expensive (Szulanski 2000, s. 10; Argote, Ingram 2000, s. 151). 
(transmitters), who adapted it for the purposes of transmission to knowledge users (practitioners/receptacles) (Parent, Roy, St-Jacques 2007, p. 82). The role of a passive practitioner (carrier) of knowledge was attributed to the knowledge user. The issue of the context, in which the transfer was carried out, was omitted as well and also the issue of the manner (method), with which the transfer was conducted. Such approaches turned out to be inadequate in the light of the practice achievements and nowadays knowledge transfer is perceived as a very complex and contextually multifactorially conditioned process (Liyanage, Elhag, Ballal, Li 2009, p. 123). It is assumed that it is impossible to consider the problem of knowledge transfer ignoring such issues as (Butler, Grice, Reed 2006, p. 629): a network of social relationships, through and within which transfer takes place, a level of trust within social relations linking people among whom knowledge transfer is conducted, a type of knowledge that is subject to transfer.

It is assumed, among others, that knowledge within loose relationships can be transferred without an intended purpose in advance, and also that fragile and superficial links between individuals can provoke the transfer of new information (as well as - what is more important - innovation), although at the same time the transfer of tacit knowledge can mainly be carried out within strong, lasting relations with a high level of trust among the relation.

The group of factors significant for the course and results of transfer includes, among others (Argote, Ingram 2000, pp. 161-164): the strategy of organization, a type and nature of activities carried out in order to conduct the transfer, the characteristics of individual entities participating in the transfer, the properties of transferred technologies and tools, the degree of adequacy of the transferred knowledge resource to the situational context, within which it is supposed to be applied. It is assumed that similar strategies of business entities act in favour of the transfer. It is also recognized that it is easier to carry out the transfer of technologies and tools with a lower level of complexity. According to L. Argote and P. Ingram (2000, p. 163) the speed of transfer and its effectiveness remains dependent, both on the credibility of the knowledge source and on the motivation and ability of the practitioner to absorb it, and the efficiency of transfer increases with the growth of the degree of the diversity of the type and nature of activities implemented in order to conduct the transfer. It is also not without significance in the opinion of these authors the issue of a physical distance dividing the knowledge source from its users, as the possibility of a direct contact with the producers and (or) users of particular knowledge facilitates the access to its area defined as tacit knowledge. In the opinion of A.K. Gupta and V. Govindarajan (2000, p. 475-476) the essential importance from the point of view of transfer 
effectiveness - and regardless of the fact whether it is carried out in the conditions of cultural homogeneity or in the conditions of cultural diversity (which turns out to be particularly significant from the point of view of further deliberations) has:

- the issue of the value of knowledge contained in the possession of the source in the opinion of the practitioner of this knowledge,

- motivation the source of knowledge reveals in the context of dissemination of this knowledge,

- the issue of the motivation possessed by the practitioner to capture the knowledge being the object of the transfer,

- the issue of the practitioner possibilities within the absorption of this knowledge.

Ch. Liyanage, T. Elhag, T. Ballal and Q. Li (2009, p. 124) in turns draw the attention to the importance of:

- the degree of similarity between the source and receptacle,

- the level of similarity of technical and structural conditions of the context the knowledge source and receptacle operate (such as: culture, style of management, internal policy)

- the necessity of occurring each additional resource of knowledge referring to how the transfer of particular knowledge can be conducted.

Moreover, according to this authors (Liyanage, Elhag, Ballal, Li 2009, p. 122 and 123) although knowledge transfer concerns any communication activity, it can also be carried out non-verbally. It restricts, however, to some extent the possibilities of using the theory of translation and the theory of the communication process for the purpose of imaging and explaining the mechanism of knowledge transfer (Liyanage, Elhag, Ballal, Li 2009, p. 119, 125 and 128). Regardless of this, the model of knowledge transfer constructed by Ch. Liyanage, T. Elhag, T. Ballal and Q. Li includes a vast majority of the above mentioned determinants recognized as significant from the point of view of the transfer course, thus it has been adopted for the purpose of the elaboration.

According to Ch. Liyanage, T. Elhag, T. Ballal and Q. Li (2009, p. 125) the process of knowledge transfer often fails in the situation when the parties participating in it, for different reasons ${ }^{3}$, are not willing to share knowledge. A successful knowledge transfer is the one, which eventually allows to obtain

3 For instance for regard of confidentially, the occurrence of cultural barriers or a threat of losing a competitive advantage 
the accumulation and assimilation of new knowledge. Therefore, according to those authors, also in the case when both sides express the willingness to share knowledge, transfer can fail due to some internal characteristics of entities participating in this process, such as limited abilities to absorb, assimilate and apply knowledge. In their opinion the transfer needs a form of participation, both from the side of the source and the receptacle - as well as - establishing between the source and receptacle a relationship (or the existence of cooperation between them). Close cooperation, and thus generating knowledge and coordinating the effective knowledge capture, shall be facilitated by frequent and intimate relationships.

In the analyzed model the transfer process has been depicted in the form of a cycle: awareness - acquisition - transformation - association - application knowledge externalization ("feedback").

The first of mentioned stages (awareness) is associated with the diagnosis of adequacy and value of the located earlier knowledge. The next stage (acquisition) was brought to the capture of externally generated resource of knowledge. However, which needs to be strongly noted, in order to make the acquired (or assimilated) knowledge useful it is necessary to relate it to already possessed knowledge, thus it should be subject to a conversion. Ch. Liyanage, T. Elhag, T. Ballal and Q. Li (2009, p. 124) emphasize that in the process of knowledge transfer, the statement "that is what I know" precedes the phrase: "that is what my knowledge is for you". Hence, the next stage highlighted by them in the analyzed model is transformation. The essence of this step is the interpretation of the acquired resource of knowledge and its compilation with the possessed earlier bodies of knowledge, due to which there is a development of already possessed knowledge. Another distinguished stage (association) was brought by authors to combining the transformed knowledge with the internal needs of the organization. In their opinion it allows to make a recognition of the potentially usefulness of knowledge. The implementation of this stage shall allow for application - the fifth and most important stage in knowledge transfer, without which the realization of all indicated stages of the knowledge transfer does not bring measurable outcomes. The effective implementation of this stage is supported by communication and cooperation. Ch. Liyanage, T. Elhag, T. Ballal and Q. Li assume that the transfer process brings benefits to all involved parties. The stage of knowledge externalization ("feedback") was referred by these authors to the acquisition by the source of processed and enriched knowledge, which is created by the practitioner in the transfer process. The authors acknowledged that in the process of knowledge transfer 
it is necessary to answer the following questions (Liyanage, Elhag, Ballal, Li 2009, p. 128):

- Who needs and what is knowledge created for?

- Who will participate in knowledge transfer?

- Where is the ideal source for knowledge acquisition located?

- What kind of knowledge is to be transferred?

- In what way?

- What factors can affect the process of knowledge transfer and to what extent?

- How can be the impact power of factors supporting transfer increased?

- What should be avoided?

- What should be done to enable the utilization of the acquired knowledge?

- Did the implemented transfer process perform its function (allow for the realization of the intended purpose)?

These authors also assume the need for the specification of indicators helping the evaluation of the conducted transfer. The undoubted advantage of the above mentioned model is that the stages of the cycle distinguished in its framework, as well as the nature of a social network, within which the transfer is carried out and the type of the transferred knowledge resource can be referred both to the level: individual - individual, individual - team, team team, team environment, team - organization, and organization - organization (Liyanage, Elhag, Ballal, Li 2009, p. 127). It is also worth noticing that the model includes the process of SECI - which is the process of knowledge generation by a conversion between tacit and explicit knowledge. Moreover, the conception of the above model approach of the transfer process remains broadly consistent with the model of the transfer process as a form of translation process (cf. Holden, Von Kortzfleisch 2004, pp. 127-136) and the transfer model as a form of learning process (cf. Kayes, Kayes, Yamazaki 2005, pp. 87-100) (both were formulated on the basis of the analysis of inter-cultural management of knowledge process), as well as with the framework conception by P.R. Carlile (cf. figure 1.).

The stages of acquisition, transformation, association and application being included in the cycle of the distinguished model by Ch. Liyanage, T. Elhag, T. Ballal and Q. Li (2009) correspond substantially to the levels of the structure of international knowledge management described by P.R. Carlile. Thus, the model seems to be more useful from the point of view of this study. 


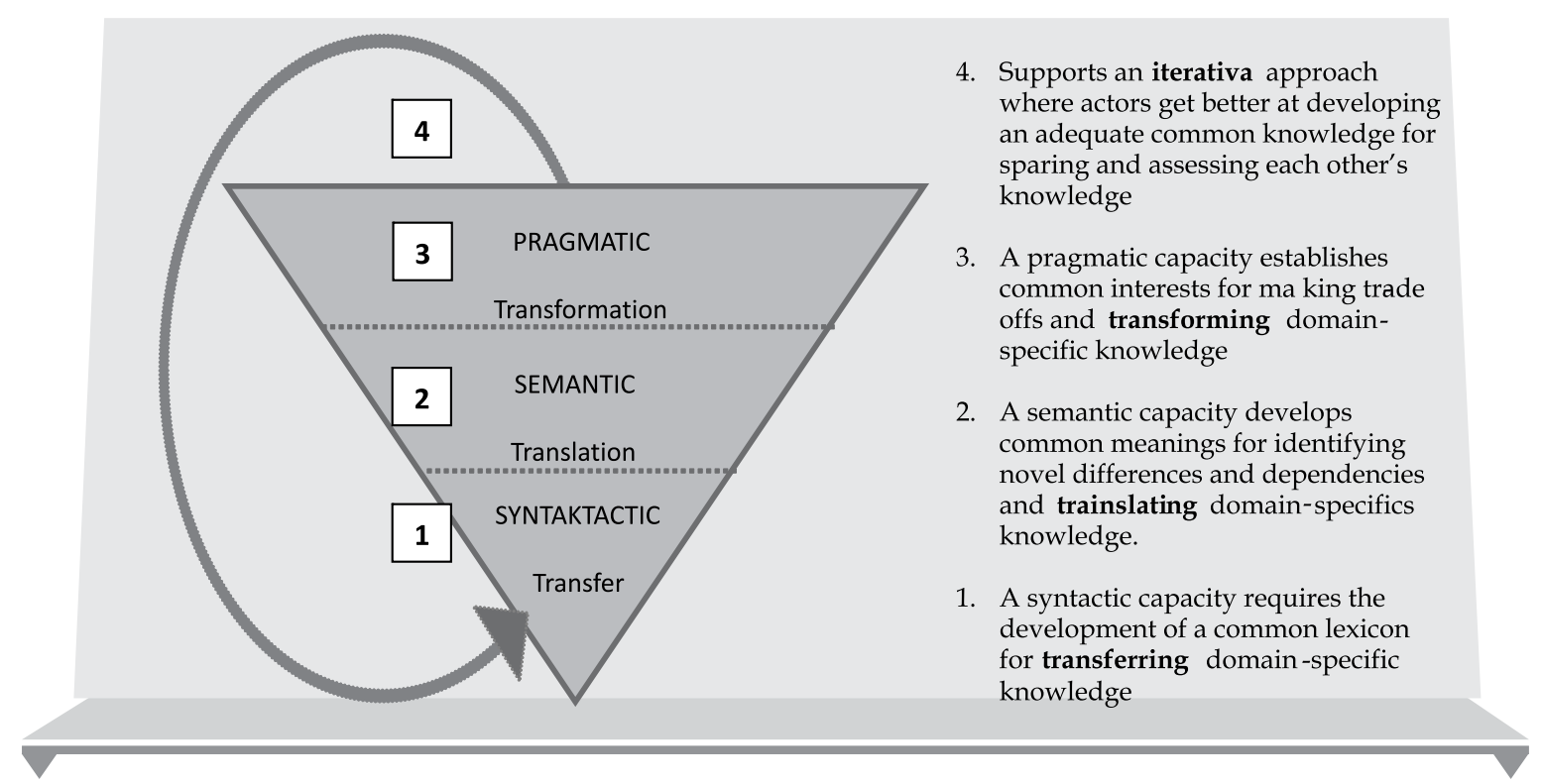

Figure 1. 3-T Framework and the Four Characteristics of a "Pragmatic" Boundary Capability

Source: Carlile, p. 563

\section{Cultural diversity in the organization}

The cultural diversity of the human resources of the organization in practice is usually considered through the prism of the national and cultural origins of employees. It is so called an inter-cultural ("horizontal") dimension of cultural diversity (when employees come from the same national culture, they differ, however, in terms of such variables as: gender, age, race/ethnic origin, social status, performed family roles, religious beliefs, sexual orientation, full - disability, professional education or occupation, it is possible to speak only about an intra-cultural dimension /"vertical"/ of diversity). In the subject literature referring to the issues of cultural diversity within the organization, the characteristics of the degree of human resources diversity is usually conducted either with the use of the proposals of culture dimensions developed by such authors as: R.R. Gestelanda (2000), G. Hofstede (2000) or F. Trompenaarsa and Ch. Hampden-Turnera (2002), or using nine dimensions developed within GLOBE project (Boski 2009).

The dissimilarity of mental programs (the patterns of cultural conditions) connected with intercultural diversity translates into differences in the patterns 
of perceiving, feeling, thinking, reasoning or reacting of people coming from different cultures, as well as differences within values, beliefs professed by people and patterns and communication styles used by them. As R.L. Wiessman (1995, pp. 118-220) emphasizes the bigger cultural distance, the smaller degree of mutual understanding between interlocutors and the more difficult for partners to communicate. Moreover, the weaknesses in a particular aspect of communication (resulting either from a lack of awareness of existing cultural differences, or from the fact of ignoring or underestimating them) depending on the kind of mistake can induce fateful consequences. The more, however, misunderstandings, mistakes, omissions, deficiencies and communication errors in the minds of cooperating people, usually the more disappointments, the worse atmosphere of cooperation and often the lower degree of mutual trust, which affects the efficiency and effectiveness of communication and cooperation in the organization (Freimuth, Krieg, Schäder 2005, p. 160). According to A.G. Canen and A. Canen (2001, p. 145) the ability to deal with cultural diversity seems to be one of the most significant factors determining the success or failure of the organization.

\section{Training and knowledge transfer}

Training, as mentioned before, is regarded as a basic form of supporting employees' development, which helps develop their competences and qualifications. In the context of the above presented content there is a justification that training can be used as a tool of knowledge transfer. It is, however, necessary to include the restrictions that are associated with using it. Firstly, the possibility of conducting knowledge transfer only with help of training is substantially limited. First of all (for regard of specific properties of tacit knowledge) it is advisable to guarantee a direct possibility of participating in the process of knowledge application, which is to subject to transfer. Training generally does not provide such a possibility. Secondly, it is necessary to take care of the motivation of target participants of training. Therefore, employees cannot be obliged to take part in the training, they should want to participate in it. Thirdly, it is important for them to possess a conviction of the value of knowledge they can acquire thanks to it, and thus to believe the training is useful for them (it is supported by the possibility of employees to exert the influence on creating its content). Fourthly, the persons conducting the training should be, in the opinion of trainees, not only reliable, but also endowed with certain trust. Finally (in any organization), deciding to carry out knowledge transfer with help of training, it 
is necessary in the process of preparing and conducting training, except obeying basic methodological rules of designing it, to take care of (own study):

1. Linking the emphasized in the methodology of preparing the training the stage of recognizing and diagnosing the problem areas with exploring and diagnosing the kind of knowledge that is to be subject to transfer, and the stage of valuing knowledge with the stage of determining priorities of the training.

2. Ensuring the participation of practitioners and trainers in developing the thematic scope of the training and its program. Its preparation cannot be entrusted only to practitioners, or solely to trainers. As mentioned before, for the sake of motivational issues, it seems reasonable to involve in the works connected with its planning the people representing the source and target practitioners of knowledge.

3. Restricting the substantive scope of the training with its diversity at the same time.

4. Conducting training modules both by the people who do not remain in lasting relationships with participants of the training, and by people who stay in a stable relation and/or who have established cooperation before (or who still are in the process of cooperation). And it is regardless of whether they are conducted in the place of the user's company, in the headquarter of the source or anywhere else. It is due to the allusive importance for the transfer process the nature of relationships that links the source and receptacle of knowledge. Adapting to this rule creates both favourable conditions for the transfer of tacit knowledge and also the transfer of novelties and innovation.

5. Resigning from the option of conducting the whole training remotely.

6. Linking the content of training with the type of work and the conditions and manner of its realization.

7. Conducting training with the use of possibly diverse techniques, both those which are based on demonstrating, discussing, acting and/or teaching others, as well as these based on listening, reading and observing.

8. Selecting the techniques and methods of training adequate to the possibilities of participants - not only for regard of their style of learning, but rather for regard of the aspect of preparing it, knowledge they possess and the type of tasks performed by them.

It is worth, however, considering the issue of conducting the training during the secondment of the group of employees to the organization, from where knowledge will be transmitted. Such a position of the training allows (provided the trainees are included in the mode of work with the use of transferred 
knowledge) for the establishment of cooperation between trainees and trainers, the development of more stable relations between them, the growth of both the reliability of the knowledge source perceived by the acquired (and the degree of trust to trainers at the same time), and also the increase of the value of this knowledge, and thus the stimulation of the level of motivation from the side of the knowledge source to knowledge sharing.

\section{Knowledge transfer in the conditions of cultural diversity}

In numerous publications in the field of management it is emphasized that the process of knowledge transfer in the conditions of cultural diversity turns out to be more complex and more difficult to carry out than in the case of culturally homogenous groups. According to the results of the research obtained by R. Jensen and G. Szulanski ${ }^{4}$ (2004, p. 517) the adaptation in order to transmit original knowledge resources substantially hinders transfer. First of all it leads to the increase of the number of communication problems between the source and receptacle, and decreasing the quality of relations between the source and receptacle results in lower efficiency within the identification of necessary knowledge and contributes to problems in the implementation of transferred knowledge. Meta-analysis conducted by A.B. Kayes, D.Ch. Kayes and Y. Yamazaki (2005, p. 92-93) proved, in turn, that the high efficiency of knowledge transfer in the cross-section of culture is supported by:

- respecting a foreign culture - because it is a natural effect of exploring a foreign culture, accepting its specificity and the ability to appreciate differences existing between own culture and a foreign one,

- developing lasting relationships with the representatives of other culture - due to the fact that closer links obtained by integrating fosters building trust and increases the degree of forbearance towards misunderstandings/mistakes,

- listening and observing - as due to it appears stronger understanding of patterns existing in a particular culture, and also of what underlies them,

- accepting the lack of clarity - due to the fact that no one is able to master the nuances of other culture (for instance with reference to non-verbal communication, existing stylistic conventions, etc.) to the extent appropriate for its native members,

4 The authors conducted the analysis of 122 two-stage transfers of organizational knowledge, both between organizations operating within a single culture and at the interface of cultures. 
- translating significant complex concepts and information from one language into another in such a way as to preserve their primary sense - the attention to this aspect allows to avoid a part of misunderstandings and unintended distortions,

- task approach - as it is reflected in the implementation of activities regardless of occurring difficulties, ambiguities and the lack of certainty as to what result will be achieved,

- thinking in terms of a team - as it is related, both to the ability to delegate powers and the possibility to ask for help.

These recommendations, in particular, should take into account the companies within which we have to deal with multicultural teams ${ }^{5}$. From the point of view of conducted deliberations, it is necessary to bear in mind the results of the research by A.K. Gupta and V. Govindarajan (2000), mentioned before in the study, according to which the level of efficiency and effectiveness of knowledge transfer in the cross-section of cultures is affected by not only the fact whether the transfer takes place in the conditions of cultural diversity and what is the level of this diversity, but the motivation of the source to knowledge transfer, the value of knowledge perceived by receptacles as well as their motivation to acquire it and their abilities within the absorption of this knowledge.

\section{Conclusions}

In the light of all issues discussed above - both those ones referring to the specificity of a knowledge transfer process, the problems of the cultural diversity of organizational staff, the conditions formulated with reference to the use of training for the purposes of knowledge transfer, as well as the conditions of knowledge transfer at the interface of cultures, it is possible to formulate some conclusions as to the problem discussed in this study. Namely:

- the use of training in the process of knowledge transfer (either at the interface of cultures or within a single culture) is possible in a similar range and will be substantially subject to the same restrictions (cf. Gupta, Govindarajan 2000),

- realizing or deepening the awareness of cultural conditions and consequences connected with them (in particular within the patterns of the implementation of communication process, styles of acting and the range of responsibility for the outcomes of undertaken tasks) may not only facilitate to establish relations and cooperation, but first of all can prevent a "natural" decrease of the level

5 As, for example at Sabre or State Street.

$\because x$

RENATA WINKLER 
of trust to "strangers" contributing to deepening them and consolidating the established relations,

- it is reasonable the consistent avoidance of the modification of knowledge resources for the transfer, with the care about translating the essence of complex concepts and information from one language into another preserving their primary sense.

However, in the case of the use of training for the purposes of transfer in a culturally diverse environment (maintaining all rules defined in this study) it seems to be particularly justified to organize an additional earlier preparations/ training, both for target knowledge users and the source of knowledge within cultural differences. It will allow to minimize threats resulting from the existing in the representatives of each culture conviction that a proper way of thinking and acting for their society is unquestionably "natural", "human-like", and therefore normal and only rational (Ferraro 2002, p. 4).

The discussed postulates do not exhaust the complexity of the analyzed issue, nevertheless in the light of conducted deliberations - similarly to keeping all defined in the study rules of the transfer itself and the use of training for the transfer (omitted in the summary) they seem to be significant to a substantial extent from the point of view of the effectiveness of knowledge transfer carried out with the use of training at the interface of cultures.

\section{Summary}

Training and knowledge transfer at the interface of cultures

The paper discusses different approaches to the problems of knowledge transfer. In the paper factors that influence crosscultural knowledge transfer with training is presented. It can be argued that the impact of national culture on the transfer of knowledge is less than the influence of such elements of the transfer process like: number of canal, source's willingness to share knowledge, sender's willingness to acquire knowledge, absorptive capacity of the receiver and to what degree Knowledge Resources was transformed.

Keywords: training, knowledge transfer, multiculturalism.

\section{Streszczenie}

Szkolenia a transfer wiedzy na styku kultur

$\mathrm{W}$ artykule omówiono prezentowane w literaturze przedmiotu podejścia do transferu wiedzy. Zasadniczą część rozważań 
poświecono problematyce barier i ograniczeń $\mathrm{w}$ transferze tego zasobu - w szczególności w odniesieniu do wykorzystania szkoleń w transferze wiedzy na styku kultur. Podkreślono, że niejednokrotnie kwestia różnic kulturowych okazuje się mniej istotna niż ilość wykorzystanych kanałów transferu, chęć dzielenia się wiedzą ze strony źródła i chęć przyswajania sobie wiedzy ze strony odbiorcy, jak również zdolności odbiorcy do absorpcji, asymilacji i zastosowania wiedzy oraz to, w jakim stopniu został przekształcony zasób wiedzy przeznaczony do transferu.

\section{Słowa}

kluczowe: $\quad$ szkolenia, transfer wiedzy, wielokulturowość.

\section{References}

1. Argote L., Ingram P. (2000), Knowledge Transfer: A Basis for Competitive Advantage in Firms "Organizational Behavior and Human Decision Processes", Vol. 82 (1).

2. Boski P. (2009), Kulturowe ramy zachowań społecznych. Podręcznik psychologii międzykulturowej, Wydawnictwo Naukowe PWN, Warszawa.

3. Butler A., Le Grice P., Reed M. (2006), Delimiting knowledge transfer from training, "Education \& Training", Vol. 48 (8/9).

4. Canen A.G., Canen A. (2001), Looking at multiculturalism in international logistics: An experiment in a higher education institution, "The International Journal of Educational Management", Vol. 15 (3).

5. Carlile P.R. (2004), Transferring, Translating, and Transforming: An Integrative Framework for Managing Knowledge Across Boundaries, "Organization Science", Vol. 15 (5).

6. Ferraro G.P. (2002), The Cultural Dimension of International Business, Prentice Hall, Upper Saddle River-New Jersey.

7. Freimuth J., Krieg R., Schäder M. (2005), Kulturelle Konflikte in deutschchinesischen Joint-Ventures: Dargestellt am Beispiel der Einführung von Konzepten der Personalführung. "Zeitschrift für Personalforschung”, Heft 2.

8. Gesteland R. (2000), Różnice kulturowea zachowania wbiznesie, Wydawnictwo Naukowe PWN, Warszawa.

9. Gupta A.K., Govindarajan V. (2000), Knowledge flows within multinational corporations, "Strategic Management Journal", Vol. 21 (4).

10. Hofstede G. (2000), Kultury i organizacje. Zaprogramowanie umystu, PWE, Warszawa.

11. Holden N.J., Von Kortzfleisch H.F. (2004), Why cross-cultural knowledge transfer is a form of translation in more ways than you think, "Knowledge and Process Management", Vol. 11 (2). 
12. Jensen R., Szulanski G. (2004), Stickiness and the adaptation of organizational practices in cross-border knowledge transfers, "Journal of International Business Studies", Vol. 35 (6).

13. Kang J., Rhee M., Kang H. (2010), Revisiting knowledge transfer: Effects of knowledge characteristics on organizational effort for knowledge transfer, "Expert Systems with Applications", Vol. 37 (12).

14. Kayes A.B., Kayes D.Ch., Yamazaki Y.(2005), Transferring Knowledge across Cultures: A Learning Competencies Approach, "Performance Improvement Quarterly", Vol. 18 (4).

15. Kumar J.A., Ganesh L.S.(2009), Research on knowledge transfer in organizations: a morphology, "Journal of Knowledge Management", Vol. 13 (4).

16. Liyanage Ch., Elhag T., Ballal T., Li Q. (2009), Knowledge communication and translation - a knowledge transfer model, "Journal of Knowledge Management", Vol. 13 (3).

17. Majchrzak A., Cooper L.P., Neece O.E. (2004), Knowledge reuse for innovation, "Management Science", Vol. 50 (2).

18. Niederman F. (2005), International business and MIS approaches to multinational organizational research: The cases of knowledge transfer and IT workforce outsourcing, "Journal of International Management", Vol. 11 (2).

19. Parent R., Roy M., St-Jacques D.(2007), A systems-based dynamic knowledge transfer capacity model, "Journal of Knowledge Management", Vol. 11 (6).

20. Qin C., Ramburuth P., Wang Y. (2008), Cultural distance and subsidiary roles in knowledge transfer in MNCs in China, "Chinese Management Studies", Vol. 2 (4).

21. Sikorski Cz. (2000), O potrzebie indywidualizmu w pracy zespołowej, in: A. Potocki (ed.), Wspótczesne tendencje w zarządzaniu. Teoria i praktyka, Wyższa Szkoła Przedsiębiorczości i Zarządzania, Chrzanów.

22. Szulanski G. (2000), The Process of Knowledge Transfer: A Diachronic Analysis of Stickiness, "Organizational Behavior and Human Decision Processes", Vol. 82 (1).

23. Trompenaars F., Hampden-Turner Ch. (2002), Siedem wymiarów kultury, Oficyna Ekonomiczna, Kraków .

24. Wiessman R.L. (1995), Intercultural communication theory, Tom 19, Sage Publications, Thousand Oaks-London-New Delhi. 